Utah State University

DigitalCommons@USU

\title{
Tall shrub dynamics in northern Minnesota aspen and conifer forests
}

J.C. Balogh

D.F. Grigal

Follow this and additional works at: https://digitalcommons.usu.edu/aspen_bib

Part of the Forest Sciences Commons

\section{Recommended Citation}

Balogh, J. C. and Grigal, D. F. 1989. Tall shrub dynamics in northern Minnesota aspen and conifer forests. Research Paper North Central Forest Experiment Station, USDA Forest Service. No. NC-283.

This Article is brought to you for free and open access by the Aspen Research at DigitalCommons@USU. It has been accepted for inclusion in Aspen Bibliography by an authorized administrator of DigitalCommons@USU. For more information, please contact

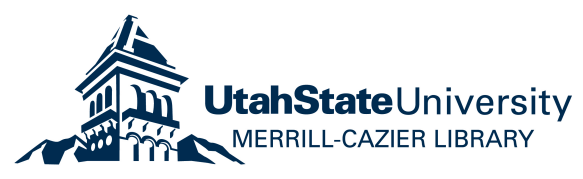


Forest

Service

North Central

Forest Experiment

Station

Research

Paper NC-283

4

Dynamics

in Northern

Minnesota

Aspen and

Conifer Forests

James C. Balogh and David F. Grigal




North Central Forest Experiment Station Forest Service-U.S. Department of Agriculture 1992 Folwell Avenue St. Paul, Minnesota 55108

Manuscript approved for publication July 21, 1988 1988 


\title{
TALL SHRUB DYNAMICS IN NORTHERN MINNESOTA ASPEN AND CONIFER FORESTS
}

\author{
James C. Balogh \\ and David F. Grigal
}

Tall shrubs are a dynamic component of upland forests in the Lake States (Balogh 1983, Dunn 1986, Ohmann and Ream 1971). They are an integral part of forest element cycles, competitors with overstory for growth and reproduction, essential to post-harvest site stabilization, and a source of wildlife cover and browse (Comerford and White 1977, Dunn 1986, Robinette 1972, Tappeiner 1971).

Most research on shrubs has been conducted in arid and semiarid ecosystems where they dominate (Johnson 1982, Louda 1982, Schlesinger and Gill 1978). Previous research on shrubs in northtemperate ecosystems has focused on single species or composite populations in a limited number of stands (Crow 1978, Reiners 1972), development of species biomass equations (Grigal and Ohmann 1977, Smith and Brand 1983), and shrubs as components of vegetation surveys and site classifications (Grigal and Ohmann 1975, Whittaker and Woodwell 1968). In the Great Lakes forests, few studies have quantitatively examined tall shrub dynamics and their relation to site characteristics.

The objective of this study was to quantitatively analyze age-density distributions of tall shrubs within conifer and aspen forests in northern Minnesota. We investigated the structure and implications of the agedensity distributions, fit to both negative exponential and power function models and compared model characteristics, including slope and intercept, to overstory characteristics and soil resources. These analyses provide information regarding life-history strategies and autecology of tall shrubs in northern Minnesota forests.

JAMES C. BALOGH, Research Scientist, Spectrum Research, Inc., 4524 Oakley Street, Duluth, MN 55804 and DAVID F. GRIGAL, Professor, Departments of Soil Science and Forest Resources, University of Minnesota, St. Paul, MN 55108.

\section{BACKGROUND}

The number of stems of each age-class present in a population, or the age-density distribution, provides important information regarding age structure, mortality, and regeneration in forest communities (Hett and Loucks 1976, Lorimer 1980, Stewart 1986). Mortality and regeneration of members of a plant community regulate plant density and affect species survival strategies.

Age-density distributions have been well documented for overstory trees and long-lived woody plant species (fig. 1). In uneven-aged forests of latesuccessional species, the age-density distribution has an inverse-j shape (Leak 1975, Whipple and Dix 1979). A unimodal or Gaussian age-density distribution has been reported for stands of even-aged trees (Knowles and Grant 1983, Stewart 1986, Yarranton and Yarranton 1975). Irregular or random age-density distributions have been associated with species that grow on marginal habitats (Whipple and Dix 1979).

Age-density distributions are usually represented by three general mathematical models (fig. 2) (Deevey 1947). Type I, or the negative skewed rectangular distribution, models are rare in perennial plant populations (Sarukhàn and Harper 1973). Herbaceous plants often exhibit a Type II, or negative exponential distribution, with constant slope for all ages. Long-lived tree species demonstrate a Type III, or power function relation, with high initial slope that decreases with age class (Hett and Loucks 1971, 1976). Harper (1977) observed that some plant species exhibit both negative exponential and power function distributions. Mathematical fitting of age-density distributions to these two models has been used to determine the most appropriate model and to quantify slopes (Hett and Loucks 1976, Hibbs 1979, Monk 1981). Qualitative assessments of deviations from models along simple environmental gradients have also been reported (Hett and Loucks 1971, 1976; Leak 1975; Lorimer 1980; Whipple and Dix 1979). 

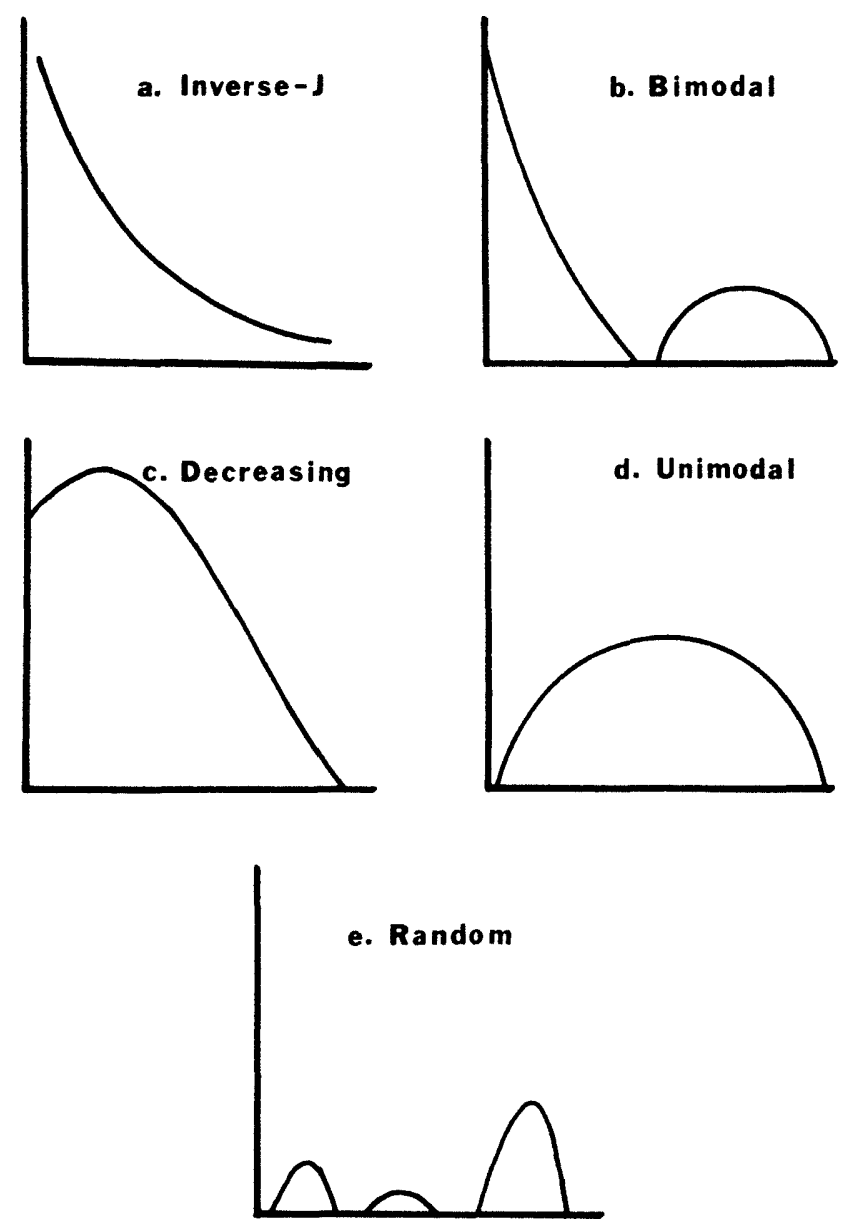

Figure 1.-Five potential age-density distributions that may be observed in natural plant populations. The horizontal axis is age and the vertical axis is the density in an age class.

Research on shrub age-density distributions and their relations to site characteristics has been emphasized for arid and semiarid ecosystems (Barbour 1969, Crisp and Lange 1976, Johnson 1982, Louda 1982). Few studies of age-density distributions or lifehistory dynamics of tall shrubs in temperate forest communities have been reported (Hibbs 1979, Marks 1974, Tappeiner 1971). Age-frequency histograms presented by Ohmann et al. (1978) suggest that common tall shrub species in northeast Minnesota have inverse-j age-density distributions.

Few studies have compared age-density distributions of tall shrubs for a series of forest communities with different site characteristics. In many northern forests, high stem densities (Ohmann and Ream 1971, Tappeiner 1971) and the requisite intensive sampling have discouraged such work.

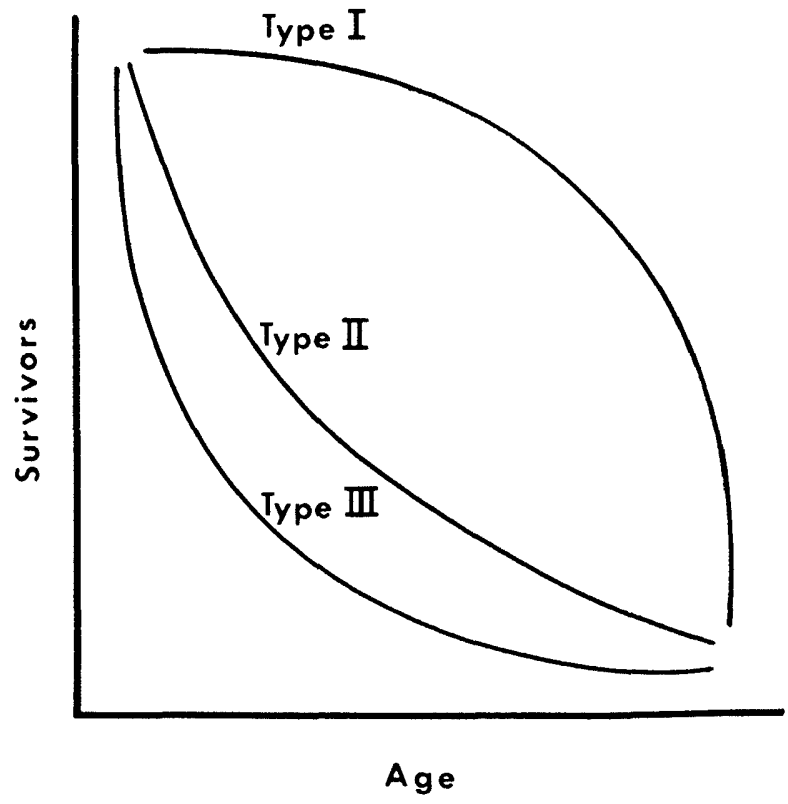

Figure 2.-Generalized shape of three types of agedensity distributions observed in natural populations. Type $I$ is the negative skewed rectangular distribution, Type II is the negative exponential distribution, and Type III is the power function distribution.

\section{METHODS}

\section{Site Selection and Site Characteristics}

Twenty-four upland forests were sampled in the Chippewa and Superior National Forests in northcentral and northeastern Minnesota (centered at $47^{\circ} \mathrm{N}, 93^{\circ} \mathrm{W}$ ) (fig. 3). Overstory trees were earlysuccessional species including trembling and bigtooth aspen (Populus tremuloides Michx.; Populus grandidentata Michx.), red pine (Pinus resinosa Ait.), and jack pine (Pinus banksiana Lamb.). Sixteen of the stands were undisturbed and were randomly selected from USDA Forest Service cover-type maps. The remaining eight stands were multiple-study sites, including silvicultural treatments of thinning, fertilizing, and cutting. All treatments had been done more than 10 years before sampling. Portions of these latter stands that differed in treatment were sampled as separate substands, yielding a total of 34 sample locations (fig. 3; table 1).

The climate of the study area is continental with short, hot summers and cold winters. Normal annual 


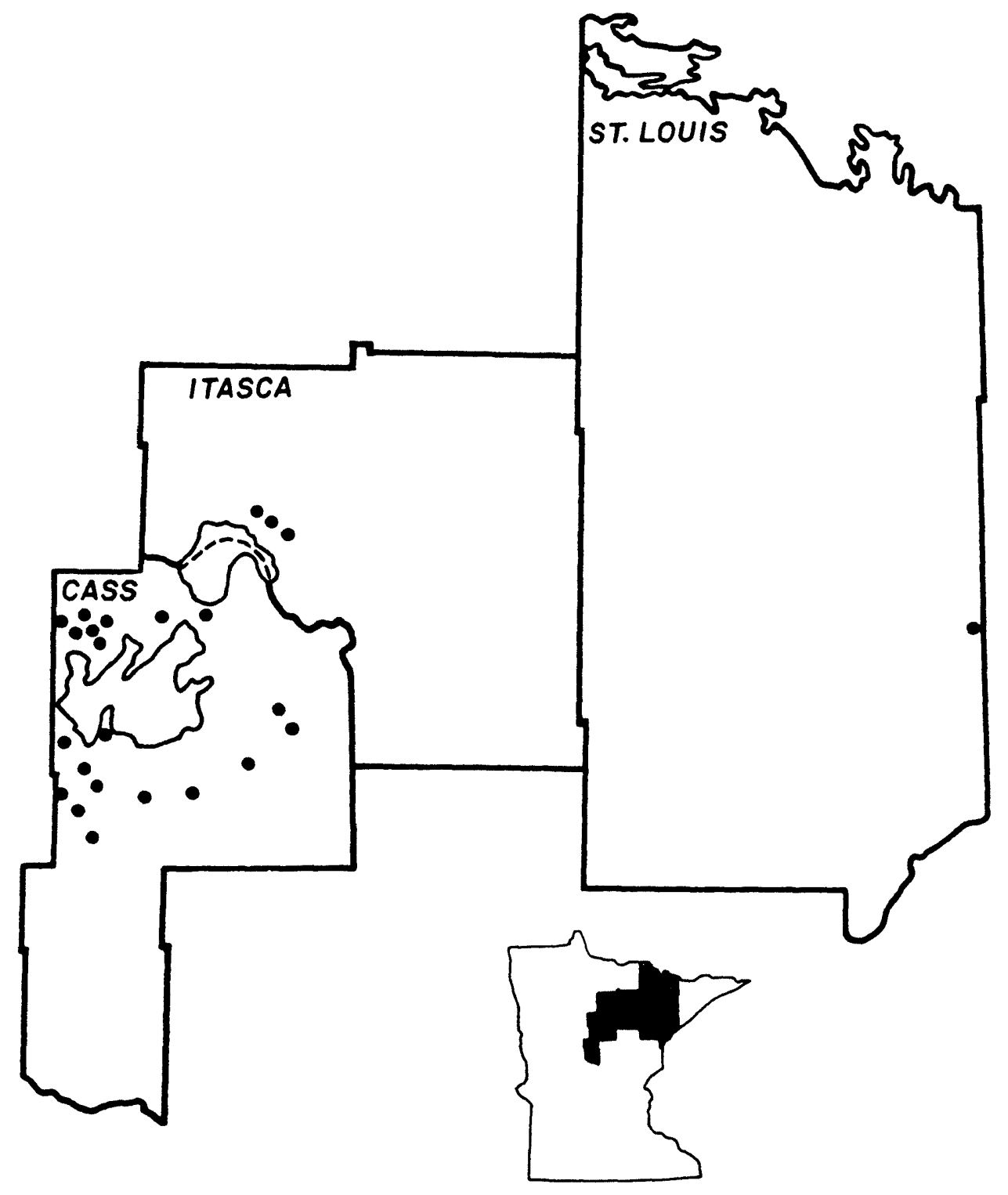

Figure 3.-Location of study sites in north-central and northeastern Minnesota.

temperature is $3.4^{\circ} \mathrm{C}$, and normal annual precipitation is approximately $68 \mathrm{~cm}$, about two-thirds of which falls during the growing season (Baker et al. 1985, Baker and Kuehnast 1978). Soil parent material is diverse and includes till, outwash, and lacustrine material deposited in the late-Wisconsin era (Cummins and Grigal 1981, Wright 1972). Soils in the Chippewa National Forest study area developed on material deposited in the Itasca moraine and Bemidji physiographic area. The Superior National Forest study area was located in the Toimi drumlin field deposited by the Rainy sublobe (Wright 1972).

\section{Shrub, Overstory, and Soil}

Vegetation was sampled systematically in each stand with a random start (Balogh 1983). A minimum of six, $5 \mathrm{~m}^{2}$ plots were used to determine shrub characteristics. These plots were nested within a similar number of contiguous $70 \mathrm{~m}^{2}$ plots that sampled the overstory. Shrub identification and nomenclature follows Gleason and Cronquist (1963). Common tall shrub species sampled included: Acer spicatum Lam., Alnus crispa (Ait.) Pursh., Amelanchier spp., Cornus alternifolia L. F., Cornus rugosa Lam., Corylus americana Walt., Corylus 
Table 1.-Overstory and site characteristics of sampled stands

ASPEN COVER TYPE

\begin{tabular}{|c|c|c|c|c|c|c|c|}
\hline Stand & $\begin{array}{c}\text { Overstory } \\
\text { basal } \\
\text { area }\end{array}$ & $\begin{array}{c}\text { Potential } \\
\text { overstory } \\
\text { productivity }\end{array}$ & $\begin{array}{l}\text { Stand } \\
\text { age }\end{array}$ & $\begin{array}{l}\text { High } \\
\text { light } \\
\text { index } \\
\end{array}$ & Treatment & $\begin{array}{l}\text { Shrub } \\
\text { density }\end{array}$ & $\begin{array}{c}\text { Dominant } \\
\text { shrubs' }\end{array}$ \\
\hline & $m^{2} / h a$ & $m^{3} / h a / y r$ & Years & Percent & & $10^{3}$ stems/ha & \\
\hline 1 & 32.1 & 6.52 & 34 & 16 & Natural & 80 & $\begin{array}{l}\text { Ac sp, Co ru, } \\
\text { Co co }\end{array}$ \\
\hline 2 & 74.6 & 6.52 & 42 & 25 & Natural & 41 & $\begin{array}{l}\text { Co co, Pr vi, } \\
\text { Co am }\end{array}$ \\
\hline 3 & 25.5 & 5.25 & 56 & 29 & Natural & 83 & $\begin{array}{l}\text { Ac sp, } \mathrm{Cr} r u \\
\text { Co co, Am }\end{array}$ \\
\hline 4 & 35.0 & 4.13 & 60 & 19 & Natural & 26 & $\begin{array}{l}\text { Co co, Cr ru, } \\
\text { Vi ra, Pr vi }\end{array}$ \\
\hline 5 & 23.3 & 5.25 & 49 & 15 & Natural & 24 & Co co, Sa \\
\hline 6 & 17.3 & 5.25 & 49 & 27 & Natural & 46 & $\mathrm{Co} \mathrm{co}$ \\
\hline 7 & 19.9 & 6.52 & 49 & 42 & Natural & 108 & $\begin{array}{l}\text { Co co, Cr al, } \\
\text { Cr ru, Co am }\end{array}$ \\
\hline 8 & 22.0 & 6.52 & 18 & 13 & Natural/Clearcut & 61 & $\begin{array}{l}\text { Co co, Am } \\
\text { Pr vi, Cr al }\end{array}$ \\
\hline $9 a$ & 33.1 & 6.52 & 38 & 11 & Natural/Control & 73 & $\begin{array}{l}\text { Co co, Co am, } \\
\text { Am, Vi ra }\end{array}$ \\
\hline $9 b$ & 23.1 & 6.52 & 38 & 25 & Natural/Thinned & 60 & $\begin{array}{l}\text { Co am, Co co, } \\
\text { Pr vi, Vi ra }\end{array}$ \\
\hline 10 & 16.1 & 7.15 & 18 & 17 & Natural/Clearcut & 83 & $\begin{array}{l}\text { Co co, Sa } \\
\text { Cr ru }\end{array}$ \\
\hline \multicolumn{8}{|c|}{ CONIFER COVER TYPE } \\
\hline 11 & 49.9 & 5.25 & 69 & 33 & Natural/Red Pine & 72 & $\begin{array}{l}\text { Co co, Am, } \\
\text { Pr vi }\end{array}$ \\
\hline 12 & 40.1 & 4.13 & 70 & 27 & Natural/Jack Pine & 286 & $\begin{array}{l}\text { Co co, Ac sp, } \\
\text { Al cr }\end{array}$ \\
\hline 13 & 42.7 & 4.13 & 87 & 36 & Natural/Red Pine & 15 & $\begin{array}{l}\text { Co co, Al cr, } \\
\text { Co am, Am }\end{array}$ \\
\hline 14 & 54.3 & 4.13 & 84 & 22 & Natural/Red Pine & 36 & $\begin{array}{l}\text { Co co, Am, } \\
\text { Pr vi, Sa }\end{array}$ \\
\hline 15 & 35.0 & 5.25 & 82 & 38 & Natural/Red Pine & 44 & $\begin{array}{l}\text { Co co, Cr ru, } \\
\text { Ac sp, Pr vi }\end{array}$ \\
\hline $16 a$ & 28.2 & 5.25 & 45 & 24 & $\begin{array}{l}\text { Plantation/Red Pine } \\
\text { Fertilized }\end{array}$ & 45 & $\begin{array}{l}\text { Co co, Pr pe, } \\
\text { Pr vi, Sa }\end{array}$ \\
\hline $16 b$ & 26.8 & 5.25 & 45 & 26 & $\begin{array}{l}\text { Plantation/Red Pine } \\
\text { Fertilized }\end{array}$ & 60 & $\begin{array}{l}\text { Co co, Sa, } \\
\text { Am, Pr vi }\end{array}$ \\
\hline $16 c$ & 28.1 & 5.25 & 45 & 32 & $\begin{array}{l}\text { Plantation/Red Pine } \\
\text { Control }\end{array}$ & 32 & $\begin{array}{l}\text { Co co, Pr vi, } \\
\text { Am, Pr pe }\end{array}$ \\
\hline $17 a$ & 25.9 & 5.25 & 69 & 23 & Natural/Red Pine & 29 & Co am, Co co, \\
\hline
\end{tabular}


Table 1.- Overstory and site characteristics of sampled stands (continued)

\begin{tabular}{|c|c|c|c|c|c|c|c|}
\hline Stand & $\begin{array}{c}\text { Overstory } \\
\text { basal } \\
\text { area }\end{array}$ & $\begin{array}{c}\text { Potential } \\
\text { overstory } \\
\text { productivity }\end{array}$ & $\begin{array}{l}\text { Stand } \\
\text { age }\end{array}$ & $\begin{array}{l}\text { High } \\
\text { light } \\
\text { index }\end{array}$ & Treatment & $\begin{array}{l}\text { Shrub } \\
\text { density }\end{array}$ & $\begin{array}{l}\text { Dominant } \\
\text { shrubs' }\end{array}$ \\
\hline & $m^{2} / h a$ & $m^{3 / h a / y r}$ & Years & Percent & \multicolumn{3}{|c|}{$10^{3}$ stems/n $/$ é } \\
\hline & & & & & Thinned & & Pr vi. Am \\
\hline $17 b$ & 29.7 & 5.25 & 69 & 18 & $\begin{array}{c}\text { Natural/Red Pine } \\
\text { Thinned }\end{array}$ & 22 & $\begin{array}{l}\text { Co co. Co am. } \\
\text { Pr vi }\end{array}$ \\
\hline $18 \mathrm{a}$ & 23.7 & 4.13 & 69 & 21 & $\begin{array}{l}\text { Natural/Jack Pine } \\
\text { Control }\end{array}$ & 82 & $\begin{array}{l}\text { Co co, Co am, } \\
\text { Cr ru }\end{array}$ \\
\hline $18 b$ & 16.5 & 2.94 & 69 & 16 & $\begin{array}{c}\text { Natural/Jack Pine } \\
\text { Thinned }\end{array}$ & 81 & $\begin{array}{l}\text { Co co. Sa, } \\
\text { Co am, Vi ra }\end{array}$ \\
\hline $19 a$ & 26.6 & 4.13 & 104 & 16 & $\begin{array}{c}\text { Natural/Red Pine } \\
\text { Thinned }\end{array}$ & 33 & $\begin{array}{l}\text { Co co, Sa. } \\
\text { Cr ru }\end{array}$ \\
\hline $19 b$ & 26.9 & 4.13 & 104 & 12 & $\begin{array}{c}\text { Natural/Red Pine } \\
\text { Thinned }\end{array}$ & 74 & $\begin{array}{l}\text { Co co, Sa, } \\
\text { Cr ru. Am }\end{array}$ \\
\hline $19 \mathrm{C}$ & 33.4 & 4.13 & 104 & 19 & $\begin{array}{c}\text { Natural/Red Pine } \\
\text { Thinned }\end{array}$ & 114 & $\mathrm{Co} \mathrm{co}, \mathrm{Al} \mathrm{cr}$ \\
\hline $20 \mathrm{a}$ & 33.4 & 6.52 & 39 & 24 & $\begin{array}{c}\text { Natural/Jack Pine } \\
\text { Fertilized }\end{array}$ & 48 & $\begin{array}{l}\text { Am, Sa, } \\
\mathrm{Al} \mathrm{Cr}\end{array}$ \\
\hline $20 b$ & 34.9 & 5.25 & 39 & 23 & $\begin{array}{c}\text { Natural/Jack Pine } \\
\text { Fertilized }\end{array}$ & 21 & $\begin{array}{l}\mathrm{Sa}, \mathrm{Al} \mathrm{Cr} \\
\mathrm{Am} . \mathrm{Co} \mathrm{CO}\end{array}$ \\
\hline $20 \mathrm{c}$ & 35.1 & 5.25 & 39 & 22 & $\begin{array}{c}\text { Natural/Jack Pine } \\
\text { Control }\end{array}$ & 31 & $\begin{array}{l}\mathrm{Sa}, \mathrm{Al} \mathrm{Cr} \\
\mathrm{Am}\end{array}$ \\
\hline $20 d$ & - & - & 8 & 50 & $\begin{array}{c}\text { Natural/Jack Pine } \\
\text { Clearcut }\end{array}$ & 41 & $\begin{array}{l}\mathrm{Sa}, \mathrm{Am} \\
\mathrm{Al} \mathrm{Cr}\end{array}$ \\
\hline 21 & 33.3 & 9.18 & 44 & 30 & Plantation/Red Pine & 22 & $\begin{array}{l}\text { Co co, Pr vi, } \\
\text { Cr ru }\end{array}$ \\
\hline 22 & 45.4 & 7.15 & 80 & 17 & Natural/Red Pine & 66 & $\begin{array}{l}\text { Ac sp. Co co, } \\
\text { Co am }\end{array}$ \\
\hline 23 & - & - & 19 & 50 & $\begin{array}{c}\text { Natural/Jack Pine } \\
\text { Clearcut }\end{array}$ & 115 & $\begin{array}{l}\mathrm{Al} \text { cr. Sa, } \\
\mathrm{Co} \text { co }\end{array}$ \\
\hline 24 & - & - & 10 & 72 & $\begin{array}{c}\text { Natural/Jack Pine } \\
\text { Clearcut }\end{array}$ & 104 & $\begin{array}{l}\text { Sa, Co co, } \\
\text { Co am, Am }\end{array}$ \\
\hline
\end{tabular}

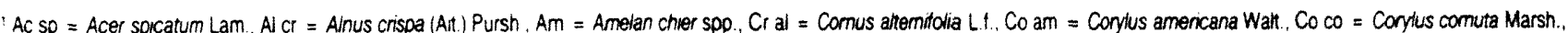
$\mathrm{Cr} r u=$ Cornus rugosa Lam. Pr pe $=$ Prunus pensylvanica L. I. Pr vi $=$ Prunus virginiana $\mathrm{L}$. Sa $=$ Salix spo., and Vi ra $=$ Vibumum rafinesquianum Schult

cornuta Walt., Prunus pensylvanica L. F., Prunus virginiana L., Ribes spp., Rosa acicularis Lindl., Rosa blanda Ait., Salix spp., and Viburnum rafinesquianum Schult.

All tall shrub stems on each $5 \mathrm{~m}^{2}$ shrub plot were cut at ground level. Tall shrubs are perennial plants having woody, permanent stems that branch from or near the ground. Mature shrub stems are between $0.5 \mathrm{~m}$ and $5 \mathrm{~m}$ tall. Stem age was determined by duplicate counts of annual rings in the field with a hand lens (magnification 10x). Additional $5 \mathrm{~m}^{2}$ shrub plots were randomly established on the periphery of the main plot until at least 100 stems of the dominant shrub species had been sampled. Stand density of shrubs by 1 year age-classes, or the age-density distribution, was determined for each species and for the total shrub population. The total shrub population was determined as the sum of all species within each stand. 
The above-ground stems of the shrubs in this study reproduce vegetatively (Tappeiner 1971). Therefore, the age distributions developed in this study refer to the age-density distributions of ramets, and not the distribution of genets. Management and analyses of shrub dynamics usually are based on the temporal and spatial distribution of shrub stems irrespective of mode of reproduction (Dunn 1986, Krefting and Ahlgren 1974, Tappeiner 1979). Forest management practices and attempts to simulate shrub abundance dynamics require information regarding the age distribution of all shrub stems.

The diameter at breast height (d.b.h.) of all trees with d.b.h. greater than $3 \mathrm{~cm}$ was recorded on each tree plot by species. Average basal area and density of the overstory were calculated. Height and age of one dominant tree per plot (six per stand) were measured, and site index was calculated (Lundgren and Dolid 1970). Site index was converted to annual productivity so different overstory species could be easily compared (table 1) (USDA Forest Service 1978). Annual productivity is the annual volume of wood accumulated on an area.

Table 2.-Soil physical and chemical properties of sampled stands
At the center of each shrub plot the overstory canopy was photographed with a $180^{\circ}$ (fisheye) lens to provide an integrated estimate of crown opening (Harcombe and Marks 1977). An index of the amount of light penetrating the forest canopy was developed by computer analysis of the photo-digitized images (table 1). The canopy was considered to be open when it allowed more than 75 percent of maximum light to penetrate, intermediate when between 25 and 75 percent of maximum light penetrated, and dense when less than 25 percent of maximum light filtered through (Balogh 1983).

A soil pit was excavated in each stand. Profile descriptions followed standard terminology (Soil Survey Staff 1951, 1981). Soil taxa identified included Eutroboralfs, Glossoboralfs, Udorthents, Dystrochrepts, and Udipsamments (Soil Survey Staff 1975, USDA Soil Management Services 1985). Percent slope of the land surface was recorded with each profile description (table 2). Samples were taken from each horizon for particle size, moisture retention, and chemical analysis. Bulk density was determined by the core method (Blake 1965). Organic soil horizons

\begin{tabular}{|c|c|c|c|c|c|c|c|c|}
\hline \multirow{2}{*}{$\begin{array}{c}\text { Stand } \\
\text { number }\end{array}$} & \multirow{2}{*}{$\begin{array}{c}\text { Weighted moisture } \\
\text { storage capacity } \\
\text { to } 150 \mathrm{~cm}\end{array}$} & \multirow[t]{2}{*}{ Slope } & \multicolumn{5}{|c|}{ Weighted nutrients to $150 \mathrm{~cm}$} & \multirow{2}{*}{$\begin{array}{c}\text { Soil } \\
\text { suborder }\end{array}$} \\
\hline & & & N & $\mathbf{P}$ & K & $\mathrm{Ca}$ & $\mathrm{Mg}$ & \\
\hline & $\mathrm{cm}$ & Percent & $\cdots$ & ....... & $\mathrm{kg} / \mathrm{ha}$ & ......... & -..... & \\
\hline 1 & 6.86 & 2 & 12,740 & 100 & 780 & 8,490 & 1,780 & Boralf \\
\hline 2 & 3.08 & 3 & 14,000 & 70 & 440 & 3,500 & 650 & Boralf \\
\hline 3 & 2.39 & 34 & 8,870 & 100 & 160 & 2,780 & 200 & Psamment \\
\hline 4 & 1.74 & 26 & 8,630 & 50 & 110 & 1,580 & 150 & Psamment \\
\hline 5 & 3.44 & 3 & 9,890 & 10 & 230 & 2,960 & 480 & Boralf \\
\hline 6 & 3.16 & 4 & 9,430 & 50 & 110 & 1,950 & 440 & Boralf \\
\hline 7 & 4.34 & 10 & 15,190 & 80 & 430 & 6,000 & 1,340 & Boralf \\
\hline 8 & 2.35 & 5 & 9,220 & 70 & 220 & 1,900 & 190 & Boralf \\
\hline $9 a, b$ & 2.22 & 3 & 10,040 & 60 & 280 & 2,860 & 400 & Boralf \\
\hline 10 & 1.84 & 2 & 8,030 & 50 & 190 & 1,750 & 190 & Orthent \\
\hline 11 & 2.06 & 15 & 7,100 & 60 & 110 & 1,430 & 160 & Orthent \\
\hline 12 & 1.32 & 35 & 10,590 & 60 & 110 & 1,910 & 240 & Psamment \\
\hline 13 & 1.35 & 2 & 15,140 & 30 & 160 & 1,150 & 130 & Psamment \\
\hline 14 & 2.49 & 10 & 5,880 & 60 & 130 & 1,920 & 210 & Boralf \\
\hline 15 & 2.40 & 9 & 4,840 & 40 & 160 & 1,750 & 260 & Boralf \\
\hline $16 a, b, c$ & 1.64 & 4 & 5,570 & 40 & 100 & 890 & 100 & Psamment \\
\hline $17 a, b$ & 1.81 & 3 & 8,930 & 50 & 100 & 1,400 & 120 & Psamment \\
\hline $18 a, b$ & 1.75 & 2 & 16,140 & 50 & 190 & 1,540 & 180 & Boralf \\
\hline $19 a, b, c$ & 2.35 & 9 & 8,810 & 80 & 100 & 1,030 & 130 & Psamment \\
\hline $20 a, b, c, d$ & 2.77 & 4 & 10,310 & 40 & 270 & 1,350 & 180 & Ochrept \\
\hline 21 & 2.00 & 16 & 10,110 & 40 & 110 & 1,170 & 120 & Boralf \\
\hline 22 & 1.76 & 40 & 9,570 & 50 & 170 & 1,120 & 140 & Psamment \\
\hline 23 & 1.91 & 2 & 7,080 & 80 & 250 & 1,720 & 220 & Orthent \\
\hline 24 & 1.18 & 2 & 10,630 & 20 & 140 & 1,080 & 140 & Psamment \\
\hline
\end{tabular}


were sampled at the center of each $5 \mathrm{~m}^{2}$ plot with a $12 \mathrm{~cm}$-diameter brass ring. Soil from the control area was sampled in stands having several silvicultural treatments.

Particle size distribution was determined by a modified hydrometer method (Grigal 1973). Moisture content on soils with sandy texture was determined at $0.01 \mathrm{MPa}$ and 1.5 and for finer-textured samples at $0.03 \mathrm{MPa}$ and $1.5 \mathrm{MPa}$ (Richards 1965). Moisture retention in organic horizons was estimated based on literature values (Balogh 1983). Water storage capacity was computed using moisture retention data, bulk density, thickness, and volume of coarse fragments. The site moisture pool was determined as a weighted average. Weighting was by an exponential function that decreased from a maximum value at the soil surface to near 0 at $150 \mathrm{~cm}$ (table 2) (Balogh 1983, Grigal and Arneman 1970).

Nitrogen content of mineral soil was determined by micro-Kjeldahl analysis (Bremner and Tabatabai 1972). Phosphorus was analyzed colorimetrically on soil extracted with Bray's No. 1 solution (Olsen and Dean 1965). Mineral soil samples were extracted with neutral $1 \mathrm{~N} \mathrm{NH}_{4} \mathrm{OAc}$ (Chapman 1965) and analyzed by an inductively coupled plasma spectrometer (ICP) to determine exchangeable bases, $\mathrm{K}, \mathrm{Ca}$, and $\mathrm{Mg}$.

Forest floor samples were dried for 72 hours at $70^{\circ} \mathrm{C}$ and ground to pass a 20-mesh screen. Samples were ashed at $500^{\circ} \mathrm{C}$ for 12 hours, dissolved in $2 \mathrm{~N}$ $\mathrm{HCl}$, and $\mathrm{K}, \mathrm{Ca}, \mathrm{Mg}$, and $\mathrm{P}$ were determined by ICP. Nitrogen in litter was estimated by regression on $\mathrm{P}$, based on data from the literature (Balogh 1983).

Nutrient concentrations were converted to mass per unit area by adjustment for horizon thickness, bulk density, and coarse skeleton volume. Stand nutrients were summed to $150 \mathrm{~cm}$ using the exponential weighting method previously described (table 2 ).

Multivariate classification techniques were used to place sampled stands in groups along synthetic gradients of resources for plant growth (Balogh 1983). These techniques were used to eliminate problems of covariance when several resources were combined to produce a gradient. A general numerical procedure was used to objectively classify the stands into groups. Non-hierarchical cluster analysis was used on the variables related to nutrients to establish an initial group classification (BMDPKM; Dixon and Brown 1979). Group classification was statistically validated via a jackknifed stepwise discriminant analysis with Mahalanobis distance probability testing (BMDP7M; Dixon and Brown 1979). Incorrectly classified stands were reclassified into the "correct" group based on the minimum discriminant distance function. The best linear combination of multivariate data for classification (first discriminant canonical variate) was recorded as the synthetic variable for analysis.

Unlike univariate groupings, which increased in value from the the first to last group, multivariate groupings and gradients are not necessarily related to increasing means of any single variable. Multivariate stand groupings included a moisture grouping based on the site moisture pool and on slope; a nutrient grouping based on quantities of $\mathrm{N}, \mathrm{P}, \mathrm{K}$, $\mathrm{Ca}$, and $\mathrm{Mg}$; and a light grouping based on the high and intermediate light index. Coefficients of shrub age-density models were related to positions along these gradients of plant growth resources.

\section{Constructing Shrub Age-Density Distributions}

For each sampled stand, age-density distributions for individual shrub species and for the entire population as the sum of all species were fit to both the negative exponential and power function models. Model fitting was by logarithmically transformed least square regression (Dixon and Brown 1979). The first model was the negative exponential distribution

$$
\mathrm{Y}=\mathrm{Y}_{\mathrm{o}} \mathrm{e}^{-\mathrm{bX}}
$$

which after transformation becomes

$$
\ln \mathrm{Y}=\ln \mathrm{Y}_{\mathrm{o}}-\mathrm{bX}
$$

where $\mathrm{b}$ is the slope, $\mathrm{Y}$ is the density of stems at ageclass $\mathrm{X}$, and $\mathrm{Y}_{0}$ is the density of age-class 0 . The second model was the power curve function

$$
\mathrm{Y}=\mathrm{Y}_{\mathrm{o}} \mathrm{X}^{-\mathrm{b}}
$$

which after transformation becomes

$$
\ln Y=\ln Y_{o}-b \ln X
$$

where the parameters are as previously defined, except $Y_{0}$ is the density of age-class 1 .

Based on statistical significance, both models (2) and (4) usually fit the entire shrub population and the dominant shrub species in a stand. Significance was determined at the 0.05 level based on an F-test of the regression (BMDP1R, Dixon and Brown 1979). A few populations and species with low densities had random age-density distributions leading to nonsignificant model fits and were rejected (Whipple and Dix 1979). 
Models were initially selected for further comparison if they met the following criteria: (a) they explained at least 50 percent of the variance in ageclass density $\left(R^{2} \geq 0.50\right.$ ), (b) they were significant at the 0.05 probability level by the analysis-ofvariance $F$-test, and (c) they confirmed the assumptions concerning model variance being constant, independent of age, and having a mean of zero. Bartlett's test was used to determine homogeneity of variance among the models for age distributions of individual species and the population (Snedecor and Cochran 1967). Current or 0 year age-class was not included in the analysis because all stems in that class were not sampled. The ephemeral survival of the 0 year age-class make it impossible to accurately sample (Harper and White 1974).

Observing the age-density distribution of a standing population is a time-specific technique used to develop stem depletion curves (Hibbs 1979, Leak 1975). In this method age structure is assumed to be constant. The assumption is met by constant input into the 0 year age-class and by the presence of a complete age distribution (Hett and Loucks 1976). Most of the stands in which shrubs were sampled had no evidence of external disturbance for at least 10 years, and probably had been undisturbed for longer. Without disturbance, sans weather fluctuations, the environmental conditions in the understory have probably remained constant. In the case of most of the shrub species, the age distributions had developed within 10 to 15 years of the sampling date. Therefore, most of the sampled shrub stems developed during a period of undisturbed stand conditions. Slopes of the age-density distributions are heavily influenced by data from stems less than or equal to 10 years old, and the data from older stems do not deviate markedly from these slopes. On that basis, we accepted the assumption of a constant age-structure for shrub stems spanning the age of stems forming the basis of best-fit models.

If the assumption of constant age-structure is accepted, the slopes of the age-density distributions are synonymous with mortality rates and the intercepts are synonymous with annual regeneration (Hett and Loucks 1976, Hibbs 1979). Because of the nonmobile status of plants, density in a given site is regulated by mortality and regeneration (Harper and White 1974). Species with a negative exponential mortality rate have a constant probability of death throughout their life span. Species showing powerfunction mortality have high initial rates of stem death that decrease with age (Harper 1977). Mathematical fitting of age-density distributions to these two models quantifies both mortality rates and annual regeneration of shrub stems.

\section{Comparing Age-Density Distribution Models}

The model with the smallest residual mean square [equation (2) or (4)], pooled across all acceptable regressions developed in individual stands, was considered to have the best fit for an individual species (Snedecor and Cochran 1967). This criterion was used because it could be quantitatively applied over all stands. If we had chosen a subjective criterion, such as a comparison of negative exponential and power function models, each stand would have to be considered individually. Age-density distributions were compared using the models with the best fit.

Equality of model slopes, or mortality rates, was tested with a slope comparison F-test (Snedecor and Cochran 1967) that also yields pooled slopes. The pooled estimates of slope and residual mean square are independent of individual model intercepts. Intercepts, or annual regeneration of shrub stems, were tested by one-way analysis of covariance of adjusted means (Snedecor and Cochran 1967). The 0.05 probability level was used in all cases as the criterion of statistical significance.

The relation between the model coefficients and overstory and soil characteristics was based on least square multiple linear regression. The dependent variable was either the intercept or slope from the model, and the independent variables were basal area of overstory trees, site productivity, stand age, percent high light ( $>75$ percent of maximum light), synthetic light gradient, site moisture pool to $150 \mathrm{~cm}$, $\mathrm{N}$ and Ca content to $150 \mathrm{~cm}$, the synthetic moisture gradient, and the synthetic nutrient gradient.

The regression models relating coefficients of the age-density models to overstory and soil characteristics were screened using Mallows' Cp criterion (BMDP9R; Dixon and Brown 1979). Relations were developed separately for aspen and conifer cover types to limit the confounding influence of overstory. Only coefficients for models of the entire population and Corylus cornuta had enough observations for meaningful regression analyses. The regression models had 0.05 probability significance for the overall regression ( $\mathrm{F}$-test) and for model coefficients (t-tests) and met the assumptions concerning regression model variance (Weisberg 1980). 


\section{RESULTS AND DISCUSSION}

\section{Developing Age-Density Distributions}

Age-density models were developed for the entire population of shrubs and for Corylus cornuta, Amelanchier spp., Acer spicatum, Cornus rugosa, Salix spp., Alnus crispa, Cornus alternifolia, Prunus virginiana, Corylus americana, and Viburnum rafinesquianum (table 3) (Balogh 1983). In many stands, both negative exponential and power function models were significant at the 0.05 probability level (fig. 4 , table 3 ).

As has been found in similar studies, some distributions deviated from the developed models (fig. 4) (Hett and Loucks 1976, Lorimer 1980). A review of the pattern of residuals among all age-density models did not reveal systematic deviations from either the negative exponential or power function distributions. The fact that the models explained more than 50 percent of the variation in the agedensity distributions, and usually more than 70 percent (Balogh 1983), indicates that most of the deviations are random variation and are not clear trends.
The best-fit models lessened this divergence. In some stands, especially those with few shrubs, age-density models did not meet all acceptance criteria. The low density of shrubs on these sites may indicate that the species were marginally adapted causing random excursions from regular age-density distributions to be more pronounced (Leak 1975, Whipple and Dix 1979)

\section{Selecting the Best Age-Density Distribution Model}

The model with the best fit to the distributions, independent of the intercept, was the one that minimized the pooled residual mean square (table 3). The total population, Corylus cornuta, Amelanchier spp., Salix spp., Cornus alternifolia, Prunus virginiana, and Corylus americana were best described by the negative exponential model. Acer spicatum, Cornus rugosa, Alnus crispa, and Viburnum rafinesquianum were best described by the power curve model.

The power curve model for Acer spicatum was similar to that found for other Acer spp. (Hett 1971,

Table 3.-Pooled parameters for tall shrub survivor models by species and population

\begin{tabular}{|c|c|c|c|c|c|c|}
\hline Species & $\begin{array}{l}\text { Model } \\
\text { type } 1\end{array}$ & $\begin{array}{c}\text { Pooled } \\
\text { mortality } \\
\text { rate,b }\end{array}$ & $\begin{array}{c}\text { Pooled } \\
\text { residual } \\
\text { mean-square }\end{array}$ & $\begin{array}{c}\text { Models } \\
\text { developed }\end{array}$ & $\begin{array}{c}\text { Regeneration } \\
\text { range; } \ln Y_{0}\end{array}$ & $\begin{array}{l}\text { Best } \\
\text { model fit }\end{array}$ \\
\hline & & & & No. & & \\
\hline \multirow[t]{2}{*}{ Total population } & 1 & 0.202 & 0.2456 & 33 & $8.04-10.99$ & 1 \\
\hline & 2 & 1.242 & .4810 & 30 & $8.40-12.00$ & \\
\hline \multirow[t]{2}{*}{ Corylus cornuta } & 1 & .221 & .3287 & 21 & $7.59-10.63$ & 1 \\
\hline & 2 & 1.139 & .5730 & 14 & $7.62-11.69$ & \\
\hline \multirow[t]{2}{*}{ Amelanchier spp. } & 1 & .157 & .2196 & 6 & $6.43-8.33$ & 1 \\
\hline & 2 & .793 & .2919 & 6 & $6.84-9.50$ & \\
\hline \multirow[t]{2}{*}{ Acer spicatum } & 1 & .154 & .3960 & 4 & $7.83-9.01$ & 2 \\
\hline & 2 & 1.237 & .1999 & 4 & $9.38-9.95$ & \\
\hline \multirow[t]{2}{*}{ Cornus rugosa } & 1 & .158 & .4699 & 4 & $6.99-7.90$ & 2 \\
\hline & 2 & .825 & .3610 & 4 & $7.09-8.69$ & \\
\hline \multirow[t]{2}{*}{ Salix spp. } & 1 & .129 & .2800 & 4 & $6.75-8.26$ & 1 \\
\hline & 2 & .782 & .4371 & 3 & $6.59-8.57$ & \\
\hline \multirow[t]{2}{*}{ Alnus crispa } & 1 & .055 & .1722 & 2 & $6.92-7.04$ & 2 \\
\hline & 2 & .592 & .1501 & 2 & $7.52 \cdot 7.68$ & \\
\hline \multirow[t]{2}{*}{ Cornus altenifolia } & 1 & .074 & .2485 & 1 & 7.41 & 1 \\
\hline & 2 & .556 & .2673 & 1 & 7.79 & \\
\hline \multirow[t]{2}{*}{ Prunus virginiana } & 1 & .193 & .1084 & 1 & 8.00 & 1 \\
\hline & 2 & .769 & .1091 & 1 & 8.12 & \\
\hline \multirow[t]{2}{*}{ Corylus americana } & 1 & .090 & .2639 & 1 & 7.70 & 1 \\
\hline & 2 & & & 0 & & \\
\hline Viburnum & 1 & .153 & .4106 & 1 & 8.16 & 2 \\
\hline rafinesquianum & 2 & 1.199 & .3555 & 1 & 9.21 & \\
\hline
\end{tabular}

1 Model number; (1) negative exponential depletion and (2) power function depletion. 

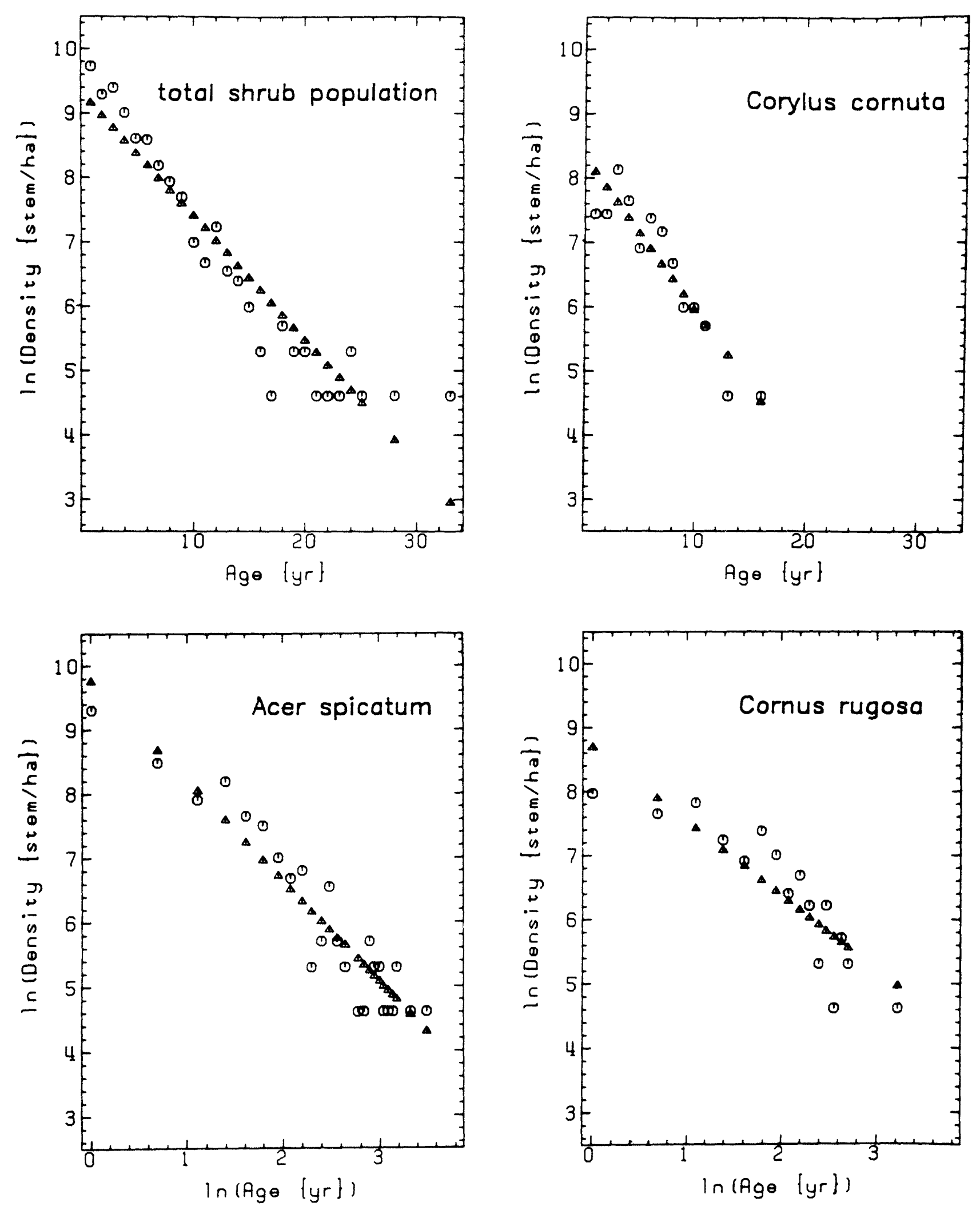

Figure 4--Observed (O) and predicted ( $\Delta$ ) age-density distribution of tall shrubs in an aspen stand. The distributions of the entire population and Corylus cornuta were described by the negative exponential age distribution model. The distributions of Acer spicatum and Cornus rugosa were described by the power function model. 
Hett and Loucks 1971, Hibbs 1979). The negative exponential model has been reported for herbaceous plants (Harper 1977), small trees (Monk 1981), and semiarid grasses (Williams 1970). The random or irregular age-density characteristic of the species with low density was similar to that of some semiarid shrubs (Barbour 1969, Goldberg and Turner 1986).

\section{Shrub Mortality Rates}

We only compared age-density distributions for those shrubs with statistically significant models in more than one stand (table 3). Such comparison requires homogeneous variance (Snedecor and Cochran 1967); generally the variances among the models for dominant shrub species and for the entire shrub population were not statistically different (table 4). Homogeneous variance implies that fluctuations in age-density relations were similar for all stands.

Slopes of the age-density distributions did not differ significantly across stands for either model type (table 4). Therefore, the mortality rates for shrub stems are independent of total shrub density, overstory, and soil characteristics. Mortality rates for tall shrubs in the sampled stands are best described by the pooled slopes of the models (table 3).

Mortality was independent of stem density and age for the shrub population and those dominant species with negative exponential age-density distributions.

Table 4.-Comparisons of tall shrub species and population age-density model presented as statistical probabilities

\begin{tabular}{|c|c|c|c|c|}
\hline Species & $\begin{array}{c}\text { Model } \\
\text { type }\end{array}$ & $\begin{array}{l}\text { Homogeneity } \\
\text { of variance } \\
\mathrm{X}^{2} \text {-probability }\end{array}$ & $\begin{array}{c}\text { Slope } \\
\text { equality } \\
\text { F-probability }\end{array}$ & $\begin{array}{c}\text { Intercept } \\
\text { equality } \\
\text { F-probability }\end{array}$ \\
\hline $\begin{array}{l}\text { Total } \\
\text { population }\end{array}$ & 1 & 0.064 & $>0.250$ & $<0.005$ \\
\hline $\begin{array}{l}\text { Corylus } \\
\text { cornuta }\end{array}$ & 1 & .047 & $>0.250$ & $<0.005$ \\
\hline $\begin{array}{l}\text { Amelanchier } \\
\text { spp. }\end{array}$ & 1 & .099 & $>0.250$ & $<0.005$ \\
\hline $\begin{array}{l}\text { Acer } \\
\text { spicatum }\end{array}$ & 2 & .411 & $>0.250$ & $<0.005$ \\
\hline $\begin{array}{l}\text { Cornus } \\
\text { rugosa }\end{array}$ & 2 & .036 & $>0.250$ & $<0.005$ \\
\hline $\begin{array}{l}\text { Salix } \\
\text { spp. }\end{array}$ & 1 & .914 & $>0.250$ & $<0.005$ \\
\hline $\begin{array}{l}\text { Alnus } \\
\text { crispa }\end{array}$ & 2 & .057 & $>0.250$ & $<0.005$ \\
\hline
\end{tabular}

However, mortality was independent of density but dependent on age for a few species with power function models, including Acer spicatum (Hibbs 1979).

\section{Shrub Regeneration}

Intercepts of the models, or annual regeneration, could be tested because of homogeneous variance and equal slopes (table 3). Regeneration of shrub stems was significantly different across the range of sampled stands (table 4). With constant stem mortality, observed as constant slopes across age-density distributions, density of tall shrubs in the studied stands is determined by steady-state regeneration.

Regression analysis of the estimated intercepts (i.e., the annual regeneration of shrub stems) as a function of overstory and soil characteristics showed few significant relations (table 5). Only one regression model was significant for stem regeneration of the entire shrub populations in conifer stands, an inverse relation to site productivity and the synthetic moisture gradient. As conifer site quality, an integration of site resources, and soil moisture decreased, regeneration of shrub stems increased. Shrubs have a rooting morphology that is advantageous for acquiring limited resources (Buckman 1964). Under conditions of limited resources, especially soil moisture, regeneration of the shrub population was favored.

In aspen stands also, only one regression model for the shrub population was significant. This was an inverse relation of the age-density model intercept to aspen basal area. As aspen basal area increased, shrub regeneration decreased. Seedlings and shrub sprouts are sensitive to competition with the deciduous aspen overstory.

The relations shown for Corylus cornuta regeneration were similar to those of the total shrub population (table 5). Regeneration of Corylus cornuta stems in conifer stands was inversely related to moisture status and overall site productivity. As with the total shrub population, annual regeneration of Corylus cornuta increased with moisture stress and depressed site quality. A positive relation of regeneration to conifer basal area appears to contradict this interpretation, but the positive trend is apparently linked to older poor-quality stands with high basal areas in the data set (Balogh 1983) (table 5).

Only one significant regression model for Corylus cornuta regeneration was found for aspen stands. Regeneration had an inverse relation to the synthetic gradient of soil nutrients, possibly because of the adaptive surface rooting morphology of Corylus cornuta for acquiring limited resources (table 5). 
Table 5.- Total shrub population and Corylus cornuta regeneration as related to selected overstory and soil characteristics in aspen and conifer stands

\begin{tabular}{|c|c|c|c|c|c|c|c|}
\hline Shrub & $\begin{array}{l}\text { Cover } \\
\text { type }\end{array}$ & Variable & Coefficient & $\begin{array}{l}\text { Coefficient } \\
\text { t-probability }\end{array}$ & $\begin{array}{c}\text { Residual } \\
\text { mean square }\end{array}$ & $\begin{array}{l}\text { Regression } \\
\text { F-probability }\end{array}$ & $\mathbf{R}^{2}$ \\
\hline $\begin{array}{l}\text { Total } \\
\text { population }\end{array}$ & Conifer & $\begin{array}{l}\text { Intercept } \\
\text { Site } \\
\quad \text { productivity } \\
\text { Moisture } \\
\quad \text { gradient }\end{array}$ & $\begin{array}{l}10.574 \\
-0.289 \\
-0.094\end{array}$ & $\begin{array}{l}0.016 \\
0.018\end{array}$ & 0.356 & 0.017 & 0.380 \\
\hline $\begin{array}{l}\text { Total } \\
\text { population }\end{array}$ & Aspen & $\begin{array}{l}\text { Intercept } \\
\text { Basal area }\end{array}$ & $\begin{array}{r}9.638 \\
-0.016\end{array}$ & 0.022 & 0.084 & 0.022 & 0.502 \\
\hline $\begin{array}{l}\text { Corylus } \\
\text { cornuta }\end{array}$ & Conifer & $\begin{array}{l}\text { Intercept } \\
\text { Moisture } \\
\text { gradient }\end{array}$ & 9.317 & 0.039 & 0.431 & 0.039 & 0.430 \\
\hline $\begin{array}{l}\text { Corylus } \\
\text { cornuta }\end{array}$ & Conifer & $\begin{array}{l}\text { Intercept } \\
\text { Basal Area } \\
\text { Site } \\
\quad \text { productivity }\end{array}$ & $\begin{array}{r}10.922 \\
0.068 \\
\\
-0.852\end{array}$ & $\begin{array}{l}0.027 \\
0.024\end{array}$ & 0.346 & 0.040 & 0.600 \\
\hline $\begin{array}{l}\text { Corylus } \\
\text { cornuta }\end{array}$ & Aspen & $\begin{array}{l}\text { Intercept } \\
\text { Nutrient } \\
\text { gradient }\end{array}$ & 8.820 & 0.041 & 0.300 & 0.410 & 0.471 \\
\hline
\end{tabular}

Soil moisture and the integrated suite of nutrients are critical for plant growth and development (Boyer 1982). Site growth resources are linked to annual recruitment of shrub stems, but regeneration was not significantly related to either overstory age or light penetration. Regeneration of shrub stems was related to overstory basal area. In aspen stands shrub regeneration appeared to compete directly with the deciduous overstory, but it did not compete with the coniferous overstories. The relation of shrub regeneration to conifer and aspen overstories is mediated through long-term site productivity and soil moisture and nutrients.

\section{CONCLUSIONS}

Both the entire population of tall shrubs and of individual dominant species demonstrated clearly defined age-density distributions in most of the sampled stands. Less-frequently occurring species also showed similar distributions in stands where they were abundant. The negative exponential function best described the age-density relation of most species and of the entire tall shrub population. The agedensity distribution of a few species was best described by a power function.

For any species, the slopes of age-density distributions, synonymous with mortality rates (Hett and Loucks 1976, Hibbs 1979), were equivalent and can be characterized by a single pooled slope. This common slope or rate occurs within the sampled stands representing a range of sites in northern Minnesota. The rate was independent of shrub density and site characteristics, and can be assumed to apply when stand conditions are stable. Mortality rates of the shrub population and of those dominant species with negative exponential distributions can be inferred to be independent of both stem density and age. The few species with power function stem depletion, including Acer spicatum, have mortality independent of density but dependent on age (Hibbs 1979).

Intercepts of the shrub age-density distributions, synonymous with annual regeneration (Hett and Loucks 1976, Hibbs 1979), were significantly different across the range of sampled stands. Because of the constant mortality rate, the wide range of tall shrub densities in the sampled stands is therefore determined by steady-state regeneration (table 1). Regeneration of shrub stems was independent of most overstory characteristics. The only exception to this conclusion was a relation of shrub regeneration to basal area. The deciduous shrub community competes with the deciduous overstory in aspen stands, but not in conifer stands. The relation of the shrub stratum to the conifer overstory may be mediated by competition for soil moisture. In conifer stands, regeneration had an inverse relation with overall site quality and soil moisture. In aspen stands, regeneration was inversely related to site nutrients. Situations in which soil moisture and nutrients were limiting appeared to favor regeneration. Tall shrubs are strong competitors under conditions of limiting moisture and nutrients. 
The results of this study, and especially the inability to detect statistical differences among the mortality rates of shrub stems, suggest an interpretation that integrates both the ecological concept of densitymortality relations and theories concerning selfthinning in plant populations (Harper 1977, Hutchings 1983, Smith 1983). Based on the observed relation between dry weight and density for a wide range of plants (Hutchings 1983, White and Harper 1970, Yoda et al. 1963), tall shrubs in all but one of the sampled stands fall below densities where densitydependent mortality rates should be manifested. Shrub mortality rates were statistically equivalent in stands with a wide range of total stem densities $(15,000$ to 286,000 stems per ha), and in many of the stands shrub densities were very high (table 1); higher densities are difficult to conceive. If density were to increase, however, mortality may become related to density. It is possible that the statistical comparison of mortality rates failed to detect differences rather than demonstrated that no differences exist.

This study aids understanding of the dynamics of tall shrubs in conifer and aspen understories. We conclude that shrub abundance is controlled by annual regeneration, not mortality rate. Therefore, those factors that affect the regeneration of shrub stems-such as the overstory, soil water and nutrients, and random historical or climatic fluctuations-will affect shrub abundance. In this analysis we considered the dynamics of tall shrubs for approximately one shrub generation. For longer time periods, where overall stand structure shifts to favor or inhibit shrub regeneration (Marks 1974, Taber and Hanley 1979, Tappeiner 1971), changing species and population densities will respond directly to those factors inducing changes in regeneration of shrub stems.

\section{ACKNOWLEDGMENTS}

This research was partially supported by Cooperative Research Agreement 13-641 between the USDA Forest Service North Central Forest Experiment Station and the Department of Soil Science of the University of Minnesota, St. Paul, Minnesota. The authors are grateful to A. L. Lundgren and L. F. Ohmann for their critical advice and invaluable assistance during the research project. The authors also thank L. F. Ohmann, S. R. Shifley, and P. A. Kosian for critically reviewing this paper. Figures were prepared by P. A. Kosian and Sandra Brovold.

\section{LITERATURE CITED}

Baker, Donald G.; Kuehnast, Earl L. 1978. Climate of Minnesota. Part 10. Precipitation normals for Minnesota: 1941-1970. Tech. Bull. 314. St. Paul, MN: University of Minnesota, Agricultural Experiment Station. $16 \mathrm{p}$.

Baker, Donald G.; Kuehnast, Earl L.; Zandlo, James A. 1985. Climate of Minnesota. Part 15. Normal temperatures (1951-1980) and their application. Tech. Bull. AD-SB-2777. St. Paul, MN: University of Minnesota, Agricultural Experiment Station. $66 \mathrm{p}$.

Balogh, James C. 1983. Tall shrubs in northern Minnesota. St. Paul, MN: University of Minnesota. 140 p. PhD dissertation.

Barbour, Michael G. 1969. Age and space distribution of the desert shrub Larrea divaricala. Ecology. 50(4): 679-685.

Blake, George R. 1965. Bulk density. In: Black, Charles A., ed. Methods of soil analysis, Part 1. Madison, WI: American Society of Agronomy. Agronomy. 9: 374-390.

Boyer, J. S. 1982. Plant productivity and environment. Science. 218: 443-448.

Bremner, J. B.; Tabatabai, M. A. 1972. Use of ammonia electrode for determination of ammonium in Kjeldahl analysis of soils. Communications in Soil Science and Plant Analysis. 3: 159-165.

Buckman, Robert E. 1964. Effects of prescribed burning on hazel in Minnesota. Ecology. 45(3): 626-629.

Chapman, H. D. 1965. Total exchangeable bases. In: Black, Charles A., ed. Methods of soil analysis, Part 2. Madison, WI: American Society of Agronomy. Agronomy 9: 902-904.

Comerford, Nicholas B.; White, Edwin H. 1977. Nutrient content of throughfall in paper birch and red pine stands in northern Minnesota. Canadian Journal of Forest Research. 7: 556-561.

Crisp, M. D.; Lange, R. T. 1976. Age structure, distribution and survival under grazing of the aridzone shrub Acacia burkittii. Oikos. 27(1): 86-92.

Crow, T. R. 1978. Biomass and production in three contiguous forests in northern Wisconsin. Ecology. 59(2): 265-273.

Cummins, J. F.; Grigal, D. F. 1981. Soils and land surfaces in Minnesota. Soil Ser. 11. St. Paul, MN: University of Minnesota, Agricultural Experiment Station. 59 p.

Deevey, Edward S. 1947. Life tables for natural populations of animals. The Quarterly Review of Biology. 22: 283-314. 
Dixon, W. J.; Brown, M. B. 1979. BMDP: biomedical computer programs p-series. Berkeley, CA: University of California Press. 880 p.

Dunn, C. P. 1986. Shrub layer response to death of Ulmus americana in southeastern Wisconsin lowland forests. Bulletin of the Torrey Botanical Club. 113(2): 142-148.

Gleason, Henry A.; Cronquist, Arthur. 1963. Manual of vascular plants of northeastern United States and adjacent Canada. New York: D. Van Nostrand Co. 810 p.

Goldberg, D. E.; Turner, R. M. 1986. Vegetation change and plant demography in permanent plots in the Sonoran desert. Ecology. 67(2): 695-712.

Grigal, D. F. 1973. Note on the hydrometer method of particle-size analysis. For. Res. Note 245. St. Paul, MN: University of Minnesota, School of Forestry. $4 \mathrm{p}$.

Grigal, D. F; Arneman, H. F. 1970. Quantitative relationships among vegetation and soil classifications from northeastern Minnesota. Canadian Journal of Botany. 48: 555-566.

Grigal, D. F.; Ohmann, L. F. 1975. Classification, description and dynamics of upland plant communities within a Minnesota wilderness area. Ecological Monographs. 45(4): 389-407.

Grigal, David F.; Ohmann, Lewis F. 1977. Biomass estimation for some shrubs from northeastern Minnesota. Res. Note NC-226. St. Paul, MN: U.S. Department of Agriculture, Forest Service, North Central Forest Experiment Station. 3 p.

Harcombe, P. A.; Marks, P. L. 1977. Understory structure of a mesic forest in southeast Texas. Ecology. 58(5): 1144-1151.

Harper, J. L. 1977. Population biology of plants. New York: Academic Press. 892 p.

Harper, J. L.; White, J. 1980. The demography of plants. Annual Review of Ecology and Systematics. 5: 419-463.

Hett, Joan M. 1971. A dynamic analysis of age in sugar maple seedlings. Ecology. 52(6): 1071-1074.

Hett, Joan M.; Loucks, Orie L. 1971. Sugar maple Acer saccharum Marsh.) seedling mortality. Journal of Ecology. 59: 507-520.

Hett, Joan M.; Loucks, Orie L. 1976. Age structure models of balsam fir and eastern hemlock. Journal of Ecology. 64: 1029-1044.

Hibbs, David E. 1979. The age structure of a striped maple population. Canadian Journal of Forest Research. 9: 504-508.

Huenneke, L. F. 1985. Spatial distribution of genetic individuals in thickets of Alnus incana spp. rugosa, a clonal shrub. American Journal of Botany. 72: 152-158.
Hutchings, M. 1983. Ecology's law in search of a theory. New Scientist. 98: 765-767.

Hutchings, Michael J.; Bradbury, Ian K. 1986. Ecological perspectives on clonal perennial herbs. Bioscience. 36(3); 178-182.

Johnson, A. F. 1982. Some demographic characteristics of the rosemary Ceratiola ericoides Michx. The American Midland Naturalist. 108: 170-174.

Knowles, Peggy; Grant, Michael C. 1983. Age and size structure analysis of Englemann spruce, ponderosa pine, lodgepole pine, and limber pine in Colorado. Ecology. 64(1): 1-9.

Krefting, Laurits W.; Ahlgren, Clifford E. 1974. Small mammals and vegetation changes after fire in a mixed conifer-hardwood forest. Ecology. 55(6): 1391-1398.

Leak, W. B. 1975. Age distribution in virgin red spruce and northern hardwoods. Ecology. 56(6): 1451-1454.

Lorimer, Craig G. 1980. Age structure and disturbance of a southern Appalachian virgin forest. Ecology. 60(5): 1169-1184.

Louda, S. M. 1982. Limitation of the recruitment of the shrub Haplopappus squarrosus (Asteraceae) by flower- and seed-feeding insects. Journal of Ecology. 70: $43-53$.

Lundgren, A. L.; Dolid, W. A. 1970. Biological growth functions describe published site index curves for the Lake States timber species. Res. Pap. NC-36. St. Paul, MN: U.S. Department of Agriculture, Forest Service, North Central Forest Experiment Station. 9 p.

Marks, P. L. 1974. The role of pin cherry (Prunus pensylvanica L.) in the maintenance of the stability in northern hardwood ecosystems. Ecological Monographs. 44(1): 73-88.

Monk, Carl D. 1981. Age structure of Carya tomentosa (Poir.) Nutt. in a young oak forest. The American Midland Naturalist. 106(1): 189-191.

Ohmann, Lewis F.; Ream, Robert R. 1971. Wilderness ecology: virgin plant communities of the Boundary Waters Canoe Area. Res. Pap. NC-63. St. Paul, MN: U.S. Department of Agriculture, Forest Service, North Central Forest Experiment Station. 53 p.

Ohmann, L. F.; Grigal, D. F; Brander, R. B. 1978. Shrub mass: data variability and changes over time. In: Proceedings, 10th North American moose conference and workshop; 1974 March; Duluth, MN: Minnesota Department of Natural Resources: $173-214$

Olsen, S. R.; Dean, L. A. 1965. Phosphorus. In: Black, Charles A., ed. Methods of soil analysis, Part 2. Madison, WI: American Society of Agronomy. Agronomy. 9: 374-390. 
Reiners, W. A. 1972. Structure and energetics of three Minnesota forests. Ecological Monographs. 42(1): 71-94.

Richards, L. A. 1965. Physical condition of water in soil. In: Black, Charles A., ed. Methods of soil analysis, Part 1. Madison, WI: American Society of Agronomy. Agronomy. 9: 128-152.

Robinette, W. L. 1972. Browse and cover for wildlife. In: McKell, C. M.; Blaisdell, J. P.; Goodin, J. R., eds. Wildland shrubs-their biology and utilization. Gen. Tech. Rep. INT-1. Ogden, UT: U.S. Department of Agriculture, Forest Service, Intermountain Forest and Range Experiment Station: 60-76.

Sarukhàn, Jose; Harper, John L. 1973. Studies on plant demography: Ranunculus repens L., $R$. bulosus L., and $R$. acris L. population flux and survivorship. Journal of Ecology. 61: 675-716.

Schlesinger, William H.; Gill, David S. 1978. Demographic studies of the chaparral shrub, Ceanothus megacarpus, in the Santa Ynez Mountains, California. Ecology. 59(6): 1256-1263.

Smith, B. H. 1983. Demography of Floerkea proserpinacoides, a forest-floor annual 1. Density. dependent growth and mortality. Journal of Ecology. 71: 391-404.

Smith, W. Brad; Brand, Gary J. 1983. Allometric biomass equations for 98 species of herbs, shrubs, and small trees. Res. Note NC-299. St. Paul, MN: U.S. Department of Agriculture, Forest Service, North Central Forest Experiment Station. 8 p.

Snedecor, George W.; Cochran, William G. 1967. Statistical methods. Ames, IA: The Iowa State University Press. 593 p.

Soil Survey Staff. 1951. Soil survey manual. Agric. Handb. 18. Washington, DC: U.S. Department of Agriculture. $503 \mathrm{p}$.

Soil Survey Staff. 1975. Soil taxonomy. Agric. Handb. 436. Washington, DC: U.S. Department of Agriculture. 745 p.

Soil Survey Staff. 1981. Examination and description of soils in the field. In: Soil survey manual. Issue 1. Directive 430-V-SSm, May 1, 1981. Washington, DC: U.S. Department of Agriculture, Soil Conservation Service: chapter 4.

Stewart, G. H. 1986. Population dynamics of a montane conifer forest, Western Cascade Range, Oregon USA. Ecology. 67(2): 534-544.
Taber, R. D.; Hanley, T. A. 1979. The black-tailed deer and forest succession in the Pacific Northwest. In: Wallmo, O. C.; Schoen, J. W., eds. Sitka black-tailed deer: proceedings of a conference; 1978 February 22-24; Juneau, AK. Juneau, AK: U.S. Department of Agriculture, Forest Service, Alaska Region: 33-52.

Tappeiner, J. C. 1971. Invasion and development of beaked hazel in red pine stands in northern Minnesota. Ecology. 52(3): 514-519.

Tappeiner, J. C. 1979. Effect of fire and 2,4-D on the early stages of beaked hazel (Corylus cornuta) understories. Weed Science. 27(2): 162-166.

U.S. Department of Agriculture, Forest Service. 1978. Forest Service Region 9 compartment prescription handbook. Ammendment 11. Washington, DC: U.S. Department of Agriculture, Forest Service. $168 \mathrm{p}$.

U.S. Department of Agriculture, Soil Management Services. 1985. Keys to soil taxonomy. Tech. Monogr. 6. Ithaca, NY: Cornell University, Agronomy Department. $244 \mathrm{p}$.

Weisberg, S. 1980. Applied linear regression. New York: John Wiley and Sons. 283 p.

Whipple, Stephen A.; Dix, Ralph L. 1979. Age structure and successional dynamics of a Colorado subalpine forest. The American Midland Naturalist. 101(1): 142-158.

White, J.; Harper, J. L. 1970. Correlated changes in plant size and number in plant populations. Journal of Ecology. 58: 467-485.

Whittaker, R. H.; Woodwell, G. M. 1968. Dimension and production relations of trees and shrubs in the Brookhaven Forest, New York. Journal of Ecology. 56: 1-25.

Williams, O. B. 1970. Population dynamics of two perennial grasses in Australian semi-arid grassland. Journal of Ecology. 58: 869-876.

Wright, H. E. 1972. Physiography of Minnesota. In: Sims, P. K.; Morey, G. B., eds. Geology of Minnesota: a centennial volume. St. Paul, MN: University of Minnesota, Minnesota Geological Survey: 561-578.

Yarranton, M.; Yarranton, G. A. 1975. Demography of a jack pine stand. Canadian Journal of Botany. 53: 310-314.

Yoda, K.; Kira, T.; Ogawa, H.; Hozumi, K. 1963. Self thinning in overcrowded pure stands under cultivation and natural conditions. Journal of Biology, Osaka City University. 14: 107-129. 
Balogh, James C.; Grigal, David F.

1988. Tall shrub dynamics in northern Minnesota aspen and conifer forests. Res. Pap. NC-283. St. Paul, MN: U.S. Department of Agriculture, Forest Service, North Central Forest Experiment Station. 15 p.

Tall shrub dynamics were examined in upland stands in northern Minnesota. Mortality rates of shrub stems did not differ among the stands. Shrub stem regeneration did differ among the stands and was related to overstory characteristics, soil moisture, and soil nutrients. Stem density was regulated by annual regeneration.

KEY WORDS: Inverse-J distribution, understory, soil. 